\title{
ВИРОБНИЦТВО ОРГАНІЧНОЇ ПРОДУКЦІЇ В УКРАЇНІ: СТАН ТА ПЕРСПЕКТИВИ
}

\section{Рецензент - кандидат сільськогосподарських наук П. В. Маціборук}

У статті розглянуто сучасний стан виробництва органічної продукиії в Украӥні. Проаналізовано розподіл органічних операторів за областями краӥни. Окреслено перспективи розвитку органічного виробництва, доиільність збільшення його масштабів за зростаючого попиту. Виявлено стримуючі фактори розвитку виробництва органічних продуктів. Запропоновано заходи державного стимулювання виробництва органічної продукиії.

Ключові слова: органічне виробництво, органічна продукиія, органічні оператори, розвиток органічного ринку.

Постановка проблеми. Ринок органічних продуктів $\epsilon$ перспективним сегментом агропромислового ринку розвинених країн світу. За даними експертів Міжнародної федерації органічного сільського господарства IFOAM і науководослідного Інституту біоземлеробства FiBL нині виробництво екологічно чистої сільськогосподарської продукції розвивається у 153 країнах світу, а обсяг ринку досягає 50-60 млрд доларів США $[16,17]$.

Це $\epsilon$ поштовхом до розвитку органічного землеробства в Україні, стимулом до вирощування екологічно чистої продукції українськими аграріями. Останніми роками в країні спостерігається збільшення обсягу внутрішнього ринку споживання органічної продукції, зростає попит на органічні продукти харчування. Виробництво органічної продукції є практичною реалізацією концепції сталого розвитку аграрного виробництва, що передбачає поєднання захисту довкілля, економічного зростання й соціального розвитку як взаємозалежних і взаємодоповнювальних елементів стратегічного розвитку держави, що гарантуватиме населенню високу якість продовольства як важливої складової продовольчої безпеки.

Аналіз основних досліджень і публікацій, у яких започатковано розв'язання проблеми. Дослідженню стану виробництва органічної продукції та перспектив його розвитку в Україні приділяється велика увага з боку таких вчених як: В. І. Артиш, Н. А. Берлач, Н. Х. Грабак, О. Т. Дудар, М. В. Капштик, М. І. Кобець, О. М. Маслак, М. К. Шикула, О. В. Шубравська та інших. Незважаючи на вагомість наукових робіт, наукове обгрунтування сутності практичних кроків щодо прискорення розвитку органічного сільськогосподарського виробництва залишається актуальним.

Мета дослідження - дослідити стан виробництва органічної продукції та визначити перспективи становлення ринку органічної продукції в Україні.

Головними завданнями є: проаналізувати сучасний стан виробництва органічної продукції; окреслити перспективи розвитку органічного виробництва; виявити стримуючі фактори розвитку виробництва органічних продуктів; запропонувати заходи державного стимулювання виробництва органічної продукції.

Результати досліджень. Світовий ринок органічної продукції почав розвиватися наприкінці минулого століття. В Україні виробництво органічної продукції проходить період становлення, а суттєвим позитивним зрушенням, що дасть можливість активізувати ринок органічних продуктів $€$ ухвалення Закону України «Про виробництво та обіг органічної сільськогосподарської продукції та сировини〉 від 03.09.2013, № 425-VII [5].

Відповідно до Закону, виробництво органічної продукції - це виробнича діяльність фізичних або юридичних осіб, де під час виробництва виключається застосування хімічних добрив, пестицидів, генетично модифікованих організмів, консервантів тощо, та на всіх етапах виробництва застосовуються методи, принципи та правила для отримання натуральної (екологічно чистої) продукції, а також збереження та відновлення природних ресурсів. Україна досягла певних результатів щодо розвитку власного органічного виробництва. Офіційні статистичні огляди IFOAM підтверджують, що, якщо на початок 2003 р. в Україні було зареєстровано 31 сертифіковане органічне господарство, то в 2014 p. їх нараховувалось вже 182, кількість операторів зросла на 151 одиницю. Загальна площа сертифікованих органічних сільськогосподарських земель у 2003 р. становила 164,449 тис. га, у 2014 р. - 400,764 тис. га, позитивна динаміка становить 23,632 тис. га (рис. 1) [14]. 


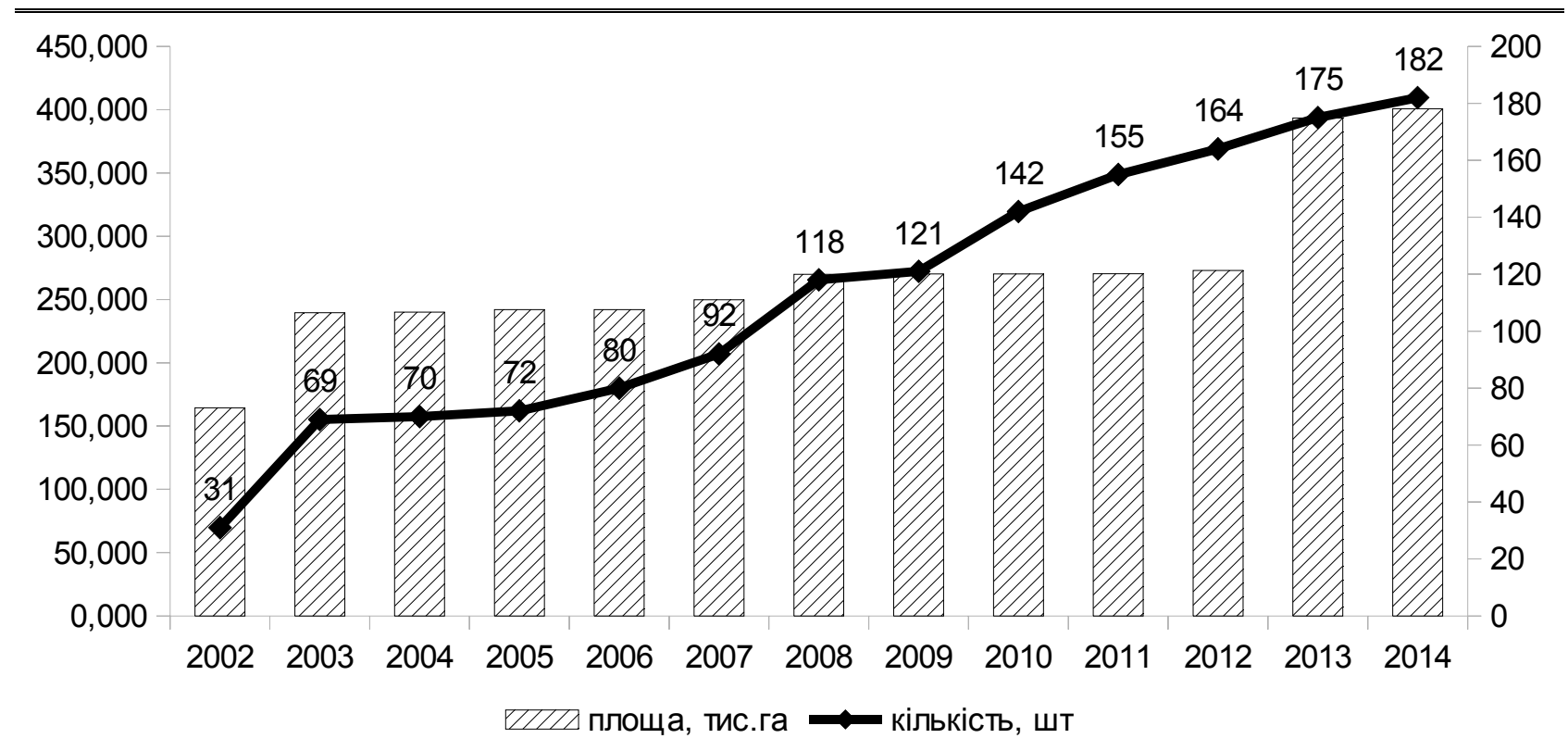

Рис. 1. Динаміка показників виробництва органічної продукцї̈ в Украӥні

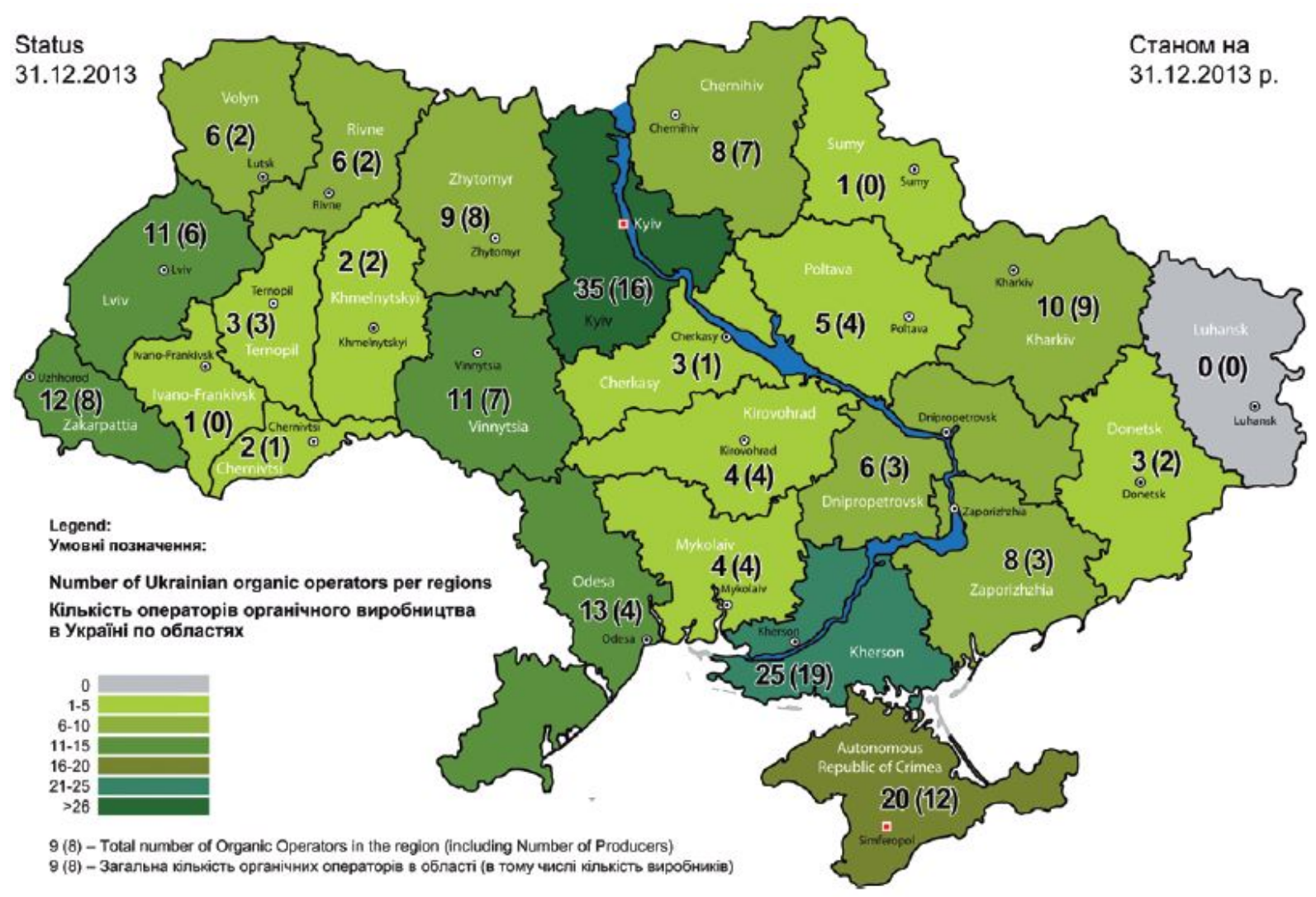

Рис. 2. Органічна карта Украӥни станом на 31.12.2013 
Частка сертифікованих органічних площ серед загального об'єму сільськогосподарських угідь України становить близько $1 \%$. При цьому Україна займає перше місце в східноєвропейському регіоні щодо сертифікованої площі органічної ріллі, спеціалізуючись переважно на виробництві зернових, зернобобових та олійних культур [14]. Серед світових країн-лідерів виробників органічної продукції наша країна займає 21 місце [6].

В Україні офіційну статистику на національному рівні щодо виробників органічної продукції не веде жоден уповноважений орган. Інформацію про сертифіковані підприємства та асортимент продукції виробників, сертифікованих 16-ма міжнародно акредитованими сертифікаційними органами, можна знайти в Органік бізнес-довіднику України [13].

Більшість господарств, які займаються виробництвом органічної продукції, розташовані на півдні країни - Одеська, Херсонська області, у західній Україні - Закарпатська, Львівська, Хмельницька області, а також у Київській, Вінницькій та Харківській областях (рис. 2) [13]. Досить часто ці господарства $є$ учасниками міжнародних проектів (зокрема зі Швейцарією та Німеччиною) щодо впровадження органічного землеробства в Україні та співпрацюють 3 іноземними компаніями. Українські сертифіковані органічні господарства - різного розміру - від кількох гектарів, як і в більшості країн Європи, до декількох тисяч гектарів ріллі [14].

Лідерами органічного агровиробництва в Україні є ПП «Агроекологія» (Полтавська обл.), група компаній «Етнопродукт» (Чернігівська обл.), ТОВ «Галекс-Агро» (Житомирська обл.), «Органічне господарство «Махаріші» (Херсонська, Миколаївська обл.), ПП «Мельник» (Вінницька обл.), ТОВ «Чистий продукт-С» (Донецька обл.) та інші [1].

Варто звернути увагу, що у Луганській області зовсім відсутні органічні оператори, хоча за сукупністю кліматичних, едафічних факторів перспективи розвитку виробництва органічної продукції досить суттєві. Крім того, кількість органічних операторів у майже половині областей коливається в незначних межах - від 1 до 5 . Це Івано-Франківська, Чернівецька, Донецька, Миколаївська, Кіровоградська, Полтавська, Черкаська, Сумська області.

Дослідження Федерації органічного руху України свідчать, що сучасний внутрішній споживчий ринок органічних продуктів в Україні почав розвиватись 3 початку 2000 -х років, стано- вивши у 2007 році 500 тис. євро, у 2008 році 600 тис. євро, у 2009 - 1,2 млн євро, у 2010 - 2,4 млн євро, у 2011 р. цей показник зріс до 5,1 млн євро, у 2012 році - до 7,9 млн євро, у 2013 р. - до 12,2 млн євро, а у 2014 р. - до 14,5 млн євро [14].

Сьогодні на органіку припадає лише 1 \% обсягу продажу продуктів харчування, хоча й спостерігається тенденція до його зростання. Споживачами цієї продукції $є$ переважно люди з середнім та високим рівнем доходу. На думку українських експертів, потенційними споживачами органічної продукції в Україні є близько $5 \%$ населення великих міст, які готові платити за неї на 30-50 \% більше, ніж за звичайну продукцію [1, 14].

Відомо, що для ведення органічного землеробства сільськогосподарські землі повинні відповідати певним вимогам щодо рівня їх забруднення шкідливими речовинами: пестицидами, важкими металами, радіонуклідами тощо. Фахівцями Інституту агрохімії і грунтознавства УААН було проведено аналіз еколого-токсикологічного стану орних земель України та виділені зони, придатні для вирощування екологічно чистої продукції [8]. Дослідження показали, що антропогенне забруднення територій в Україні має не суцільний, а локальний характер.

За даними [2], в Україні залишилось чотири невеликих регіони, де можливе вирощування екологічно чистої продукції на рівні найсуворіших світових стандартів: 1) ПівнічноПолтавський - охоплює більшу частину Полтавської області, північно-західні райони Харківської області, південно-західні райони Сумської області, південно-східні райони Чернігівської області та східні райони Київської і Черкаської областей (лівобережна частина); 2) ВінницькоПрикарпатський - тягнеться широкою смугою близько 100 км від м. Попельня Житомирської області і простягається до півночі Вінницької, Хмельницької та Тернопільської областей у напрямку до м. Львова; 3) Південно-Подільський включає невелику південно-східну частину Вінницької області, південно-західну частину Кіровоградської області, північ Миколаївщини і північну половину Одеської області; 4) Північносхідно-Луганський - охоплює Міловський і Новопсковський райони Луганської області.

На території Луганської області не сертифіковано жодного оператора органічного виробництва [13], проте північна ії частина входить до північно-східно-Луганського регіону, який визначений як безпечний щодо виробництва екологічно чистої продукції. Безпечними є також півден- 


\section{СІЛЬСЬКЕ ГОСПОДАРСТВО. РОСЛИННИЦТВО}

но-західні райони Сумської області (один оператор органічного виробництва), частина Тернопільської області (три оператори органічного виробництва), деякі райони Миколаївської області (чотири оператори органічного виробництва).

За твердженнями М. I. Кобця [9] лише наявності територій, потенційно придатних для ведення органічного землеробства, ще недостатньо. Перехід від інтенсивних технологій агровиробництва до органічного землеробства (конверсійний період) є досить тривалим процесом (від 2 до 5 років). Проблеми конверсійного періоду об'єднують у три групи $[9,12]$ : соціально-психологічні, інституційно-правові та фінансово-економічні.

До основних чинників, які стримують виробництво органічних продуктів, П. С. Зоря, С. В. Мамалига, Л. В. Породіна відносять наступні $[6,10$, 12]: нерозвиненість внутрішнього ринку, домінування імпортної органічної продукції на ринку, недостатня розвиненість інфраструктури торгівлі органічною продукцією, наявність недобросовісних виробників на ринку, недосконалість нормативно-правової бази, недостатня кількість офіційно зареєстрованих сертифікаційних центрів, слабкий розвиток інтеграції 3 міжнародними структурами та обмежений доступ на зовнішні ринки органічної продукції, відсутність державної підтримки, недостатня просвітницька робота.

Уряди багатьох розвинених країн розробили системи стимулювання та заохочування виробників органічної продукції. Так, у Німеччині обсяг державної підтримки становить 170-750 євро/га, Швейцарії - 162-970, Франції - 80-900, Нідерландах - до 650, Польщі - 66,6-394,5, Литві - до 376 євро/га. За такого підходу поліпшується не тільки якість продукції та забезпечується охорона довкілля, а й економніше використовуються енергетичні ресурси $[7,15]$. Натомість українські виробники органічної продукції державної підтримки не мають [6], а суттєву фінансову підтримку розвитку органічного сектору в Україні надають донори зі Швейцарії, Нідерландів, Франції, Німеччини та інших країн [12].

Варто зазначити, що вітчизняними вченими розроблено економічний механізм стимулювання виробників органічної продукції, основними елементами якого $€[10]$ : економічні важелі i стимули (пільгове оподаткування, підвищення розміру доплат до закупівельної ціни, пільгові ціни на послуги і засоби виробництва, державне страхування); економічні санкції (застосовуються до забруднювачів навколишнього середовища через зниження цін на екологічно забруднену продукцію, систему штрафних санкцій за нераціональне використання природних ресурсів).
В Україні існує великий потенціал для виробництва сертифікованої органічної продукції. Незважаючи на проблеми становлення, органічний сектор є перспективним завдяки родючим чорноземним грунтам, сприятливим кліматичним умовам, низьким цінам на оренду землі, зростаючому попиту населення на органічні продукти харчування [6] тощо. У порівнянні з європейськими країнами, в нашій країні наявні значні площі без істотного застосування агрохімікатів, які можна було б швидко перевести на сертифіковане органічне виробництво [9]. Органічне агровиробництво має великий потенціал для покращання економічного, соціального та екологічного стану в Україні, воно сприятиме комплексному розвитку сільських територій, поліпшенню якості та безпечності харчування населення [3]. На думку О. І. Шкуратова, В. А. Чудовської, А. В. Вдовиченко [15], органічне виробництво передбачає екологічно безпечне та соціально орієнтоване ефективне ведення сільського господарства, що дає змогу отримати стабільний прибуток, забезпечуючи рентабельність господарювання за рахунок використання природної родючості грунтів і значної економії за окремими статтями витрат. Окрім того, відбувається зростання економічного ефекту паралельно 3 поліпшенням у соціально-економічному розвитку аграрного сектора економіки. А підвищення ефективності сільськогосподарського виробництва варто здійснювати шляхом обов'язкового врахування екологічної складової задля забезпечення збалансованого розвитку суспільства.

Для вітчизняних органістів економічно найвигіднішою перспективою наразі є реалізація органічної продукції за межі країни. Експорт української органічної продукції виглядає досить привабливо, особливо для європейських трейдерів, що гостро відчувають нестачу в органічному продовольстві для задоволення потреб населення. Головним експортним ринком для українських органічних продуктів є Європейський Союз, США, Канада, Японія [6]. За твердженнями [12], органічна продукція, вироблена в Україні здатна витримати відповідність міжнародним стандартам i бути конкурентоздатною на світовому ринку.

Здатність української органічної продукції вступити у боротьбу за світовий ринок екологічно безпечної та генно-немодифікованої продукції підтверджують і С. В. Журавель та інші [4]. Це одна $з$ потенційних ніш для України в недалекому майбутньому. Зараз цей ринок лише утворюється, його дві головні проблеми - недостатня розкрученість самої ідеї чистої продукції та труднощі зі зберіганням та логістикою. 


\section{СІЛЬСЬКЕ ГОСПОДАРСТВО. РОСЛИННИЦТВО}

Висновок. Проведене дослідження дає змогу зробити висновки, що в Україні простежуються загальносвітові тенденції до популяризації виробництва органічної продукції. Органічне виробництво повільно, але розвивається: за період 3 2003 до 2014 рр. кількість органічних господарств зросла у 6 разів і наразі становить 182 одиниці; площа, зайнята органічним виробництвом збільшилася у 2,4 рази й становить 400,764 тис. га (1\% від загальної площі сільськогосподарських угідь). Лідерами за кількістю органічних господарств є Київська, Херсонська області. Слід активізувати розвиток виробництва органічних продуктів у тих областях країни, де їхня кількість незначна - в Луганській, Сумській, ІваноФранківській, Чернівецькій областях.

На сьогоднішній день Україна має значний потенціал розвитку виробництва органічної продукції. Продукція органічного походження стає все більш привабливою як для європейського, так і для національного споживача. Враховуючи те, що Україна має потужний потенціал агропромислового комплексу, країна може стати одним із головних експортерів цієї продукції на ринку СС.

\section{БІБЛІОГРАФІЯ}

1. Белясва $H$. В. Сучасний стан виробництва органічної продукції в Україні та світі/ Н. В. Бєляєва // Інноваційна економіка. - 2013. №1. - C. 151-155.

2. Відтворення родючості грунтів у грунтозахисному землеробстві / [під. ред. М. К. Шикули]. - К. : Оранта, 1998. - 680 c.

3. Грабак H. X. Виробництво екологічно чистих продуктів харчування - найперспективніший напрям агропромислового комплексу України / Н. Х. Грабак // Наукові праці Чорноморського державного університету імені Петра Могили комплексу «Києво-Могилянська академія». Серія : Екологія. - 2012. - Т. 206, Вип. 194. C. $126-131$.

4. Журавель С. В. Особливості органічного землеробства на Поліссі [Електронний ресурс] / С. В. Журавель, Б. В. Матвійчук, Н. Г. Матвійчук // Збірник наукових праць ННЦ «Інститут землеробства НААН». - 2011. - Вип. 1-2. - С. 86-94. Режим доступу : http://agriculture.kiev.ua/wpcontent/uploads/2011/04/13.pdf.

5. Закон України «Про виробництво та обіг органічної сільськогосподарської продукції та сировини» від 03.09.2013, № 425-VII [Електронний ресурс] / Верховна Рада України. - Режим доступу : http://zakon5.rada.gov.ua/laws/show/425-18.

6. Зоря П. С. Виробництво екологічно чистої
Для удосконалення й росту виробництва органічної продукції уже сертифікованими операторами органічного виробництва та заохочення й підтримки, створення нових підприємництв органічного ринку необхідне удосконалення нормативно-правової бази щодо виробництва органічної продукції та іiї гармонізація відповідно до вимог європейських Постанов, Регламентів, Директив. Розвиток органічного виробництва в Україні можливий лише за умови державної підтримки. Державне стимулювання може бути реалізоване через фінансову підтримку, пільгове оподаткування, підвищення розміру доплат до закупівельної ціни, пільгові ціни на послуги i засоби виробництва, державне страхування, популяризацію органічної продукції серед виробників і споживачів, створення розгалуженої інфраструктури ринку органічних продуктів. У такому випадку вітчизняний агровиробник здатний забезпечити виробництво достатньої кількості органічної продукції, що буде сприяти, з одного боку, покращанню стану навколишнього середовища, з іншого, - зростанню вітчизняного сільського господарства та стане досить значущою складовою підвищення рівня здоров'я нації.

продукції: проблеми та виклики сьогодення / П. С. Зоря // Економіка і управління. - 2014. №3. - C. 45-50.

7. Капштик M. В. Нормативно-правове забезпечення органічного виробництва в Україні: проблеми та перспективи / М. В. Капштик // Агроекологічний журнал. - 2012. - №1. - С. 25-31.

8. Кисіль B. I. Біологічне землеробство в Україні: проблеми і перспективи / В. І. Кисіль. - Х. : вид-во «Штрих», 2000. - $161 \mathrm{c.}$

9. Кобець М. I. Органічне землеробство в контексті сталого розвитку [Електронний ресурс] / M. I. Кобець // Проект «Аграрна політика для людського розвитку». - К., 2004. - 22 с. - Режим доступу : http://www.undp.org.ua/agro/pub/ua/P2004 01_051_04.pdf.

10. Ковальчук С. Я. Виробництво органічної продукції - аграрна спеціалізація України на міжнародному ринку / С. Я. Ковальчук, Л. В. Муляр // Збірник наукових праць ВНАУ. - 2013. - №3 (80). - C. 104-110.

11. Мамалига С. В. Розвиток ринку органічної продукції в Україні / С. В. Мамалига, О. П. Глубока // Збірник наукових праць Таврійського державного агротехнологічного університету. - 2012. - №2 (28). - Т. 1. - С. 270-279.

12. Породіна Л. В. Сучасний стан регулювання ринку безпечного продовольства: світовий 
досвід / Л. В. Породіна // Товарознавство та інновації. - 2013. - Вип. 5. - С. 188-197.

13. Органік бізнес-довідник України [Електронний ресурс] / [за ред. Н. Прокопчук, Т. Зігг, Ю. Власюк]. - 2014. - Вип. 2. - 405 с. - Режим доступу : http:/www.ukraine.fibl.org/fileadmin/documentsukraine/UKRAINE_ORGANIC_BUSINESS_DIRE CTORY_part2.pdf.

14. Офіційний веб-сайт Федерації органічного руху України [Електронний ресурс]. - Режим доступу : http://www.organic.com.ua.

15. Шкуратов O. I. Органічне сільське госпо- дарство: еколого-економічні імперативи розвитку : монографія / О. І. Шкуратов, В. А. Чудовська, А. В. Вдовиченко. - К. : ТОВ «Діа», 2015. - 248 с.

16. International Federation of Organic Agriculture Movements [Електронний ресурс]. - Режим доступу : https://www.ifoam.bio/.

17. Willer $H$. The World of Organic Agriculture. Statistics and Emerging Trends 2013 / H. Willer, J. Lernoud, L. Klicher. - Bonn : Research Institute of Organic Agriculture (FiBL), Frick and IFOAM Organic International, 2013. - 340 p. 